\title{
Virtual Practice Teaching of Project Management Based on The Sand Table Simulation
}

\author{
Feng WANG ${ }^{1, a}$, Ning ZHANG ${ }^{2, b}$ \\ ${ }^{1}$ College of Civil Engineering, Dalian Nationalities University, Dalian 116650, China \\ ${ }^{2}$ School of Fashion, Dalian Polytechnic University, Dalian 116003, China \\ awin_0803@163.com, bzhangninglady@sina.com
}

Keywords: Sand table simulation, Project management, Teaching reformation, Virtual practice teaching

\begin{abstract}
The project management sand table simulation integrates knowledge and interest and combines engineering implementation with cost accounting, being able to reflect intuitionally engineering project implementation process and the cooperation and restriction between all relevant departments in a project. It helps students understand professional knowledge and increase the interest in study and solves the problem of the students in the engineering management specialty with practicing difficulty. The thesis explains the importance of the engineering management specialty applying sand table in simulation teaching, analyzes the characteristics of and problems existing in the present engineering project management sand table simulation teaching and makes specific suggestions on perfecting the practical sand table simulation teaching.
\end{abstract}

\section{Introduction}

The engineering management specialty has such characteristics as compositeness and technical integration and is a practically applied subject. Therefore, there is a high requirement for cultivation of the practicing ability of graduates. According to the investigations made in recent years, employers generally think that the graduates from engineering management specialty are weak in practicing ability and lack of perceptual knowledge about actual engineering process and lack of a basic and global concept about the problems to be solved in a project ${ }^{[1]}$. How to improve the practicing ability of the students in the engineering management specialty in school is a key problem to be solved at present ${ }^{[2]}$.

The practical teaching in the engineering management specialty generally consists of such modes as curriculum design, production practice and school-enterprise cooperation, etc. As the a lot of people are involved in practical teaching, the time is short and the construction site management tends to increasingly more strict, etc., all these restrictions make the existing practical teaching mode not satisfactory in effect. Hence, such a teaching mode as engineering project management sand table simulation was born at the right moment. The engineering project management sand table simulation uses sand table as the carrier and sets up an imitated engineering project management market competition environment, being a kind of teaching mode of experiencing type highlighting direct involvement ${ }^{[3]}$. Students play different manager roles in the virtual project department, and get familiarized with engineering project management procedures through a series of operations such as developing progress schedule, purchasing materials, leasing equipment, personnel arrangement, organizing construction, etc. on basis of analyzing the characteristics of an engineering project and master professional knowledge and scientific management rules in decision-making. The investment cost of sand table simulation teaching is not high and students can practice without leaving school. For such specialty classes as numerous in students, students can experience by groups, by lots ${ }^{[4-7]}$. This teaching mode is suitable for the characteristics of the schools of higher learning in China ${ }^{[8]}$.

The presentation and application of the sand stable simulation practice mode improves to some degree such a deficiency as little practice by the students in the engineering management specialty ${ }^{[9]}$. However, it is still pending for further improvement. 


\section{Characteristics of project management sand table simulation}

The main process of project management sand table simulation is listed in table $1^{[10]}$, and the main characteristics of engineering project management sand table simulation teaching are:

(1) Strong sense of onsite experiencing.

6 students are formed into one group (each class can be divided into a number of groups) to implement a virtual project. The top arrangement of a sand table is like an actual engineering site, including manpower, materials, machineries, funds, etc. The engineering project operation is absolutely clear and there is a strong sense of onsite experiencing.

(2) Roles are straightforward in work division.

The roles here mainly refer to the capacities in which students are involved in an engineering project. In terms of all parties involved in engineering project management, there is mainly employer party, construction party, supplier part, design party, etc. All parties participate in project implementation according to established organizational procedure relation. That is, among the group members, the tutor will arrange them to act as different participating party roles.

(3) Complete in experimental contents.

The experimental contents of the sand table contain financing for engineering project, cost control, progress control, safety management, contract management and information management, etc., reflecting fairly comprehensively a kind of operational condition in the stage of engineering project implementation.

Table 1 . The process of project management sand table simulation

\begin{tabular}{|c|c|}
\hline Course stage & Contents \\
\hline \multirow{3}{*}{ Project startup } & $\begin{array}{l}\text { Establishment of project department, determination the } \\
\text { organization and project manager }\end{array}$ \\
\hline & Investigation of resource environment \\
\hline & $\begin{array}{l}\text { Accessing to construction information (construction task, } \\
\text { period, contract budget, engineering quality, etc.) }\end{array}$ \\
\hline \multirow{3}{*}{ Project plan } & Drawing schedule (Gantt Chart) \\
\hline & $\begin{array}{l}\text { Making labor plan, material plan, mechanical plan and capital } \\
\text { plan }\end{array}$ \\
\hline & Drawing construction cost plan \\
\hline \multirow{3}{*}{$\begin{array}{c}\text { Project } \\
\text { implementation }\end{array}$} & Project financing \\
\hline & $\begin{array}{l}\text { Purchasing materials, labor subcontracting and mechanical } \\
\text { lease }\end{array}$ \\
\hline & Engineering settlement \\
\hline \multirow{3}{*}{ Project monitoring } & Analysis of project cash flow \\
\hline & Analysis of project schedule \\
\hline & Analysis of project cost \\
\hline Project assessment & Group discussion, summary and course assessment \\
\hline
\end{tabular}




\section{Problems existing in project management sand table simulation}

The existing engineering project management sand table simulation has overcome to some degree such a deficiency as abstract, ambiguous knowledge of students about the engineering project management practice link, improved to some degree the study effect of students. However, the following problems still exist:

(1) Incomplete simulation of engineering project implementation stage

At present, the engineering project management sand table in some domestic software companies still adopt two independent systems for engineering project management and bidding management simulation operation. No corresponding simulation system has been developed for the project management in the early stage of design and the design stage. Therefore, supplement to the comprehensiveness of engineering project management sand table is pending.

(2) The simulated items are too simple.

In the simulation items introduced by some software companies, some very simple items are designed in order to speed up the project simulation process, for example, a gate, a simple bridge, etc. For complicated projects in practice, the present sand table simulation teaching system still can not simulate.

(3) The teacher force is not good.

The source of teachers is unitary and there are a lot of barriers for appropriate people with practical experience in relevant disciplines to enter into schools of higher learning. A lot of young teachers assume teaching tasks directly after graduating from schools of higher learning, whose theoretical foundation is solid but are lack of practical experience in engineering project management. Their operating ability and the ability to adapt themselves to circumstances are pending for improvement. It is difficult for them to be competent for sand table simulation teaching and guiding work.

\section{Suggestions on perfecting engineering project sand table simulation practice teaching}

(1) Strengthen laboratory construction, make good preparations in early stage

In additional to such teaching aid as sand table, the engineering project management simulation teaching has a very high requirement for the laboratory hardware environment. The fund investment in the initial laboratory construction requires emphasis and support by school. At the same time, soft platform construction should also be strengthened, including sand table simulation textbook construction, laboratory opening system construction, database construction, etc. As the comprehensiveness of sand table simulation teaching is very strong which covers most of the main courses in the engineering management specialty, it is necessary to break through specialty restriction by transferring backbone teachers from different teaching and research sections for "coordinated" teaching, joint design, collective lesson preparation and assuming the sand table simulation teaching tasks.

(2) Strengthen training to teachers and pay attention to process guidance

In the engineering project management sand table simulation course, most of students can combine the simulation process with the professional theoretical knowledge they have learned before and their practical experience. The tutors should take advantage of these opportunities sufficiently to help student integrate knowledge. At this point, a teacher is no longer an instructor but plays a different role, such as mobilizer, observer, analyzer and guider and business advisor, etc. Therefore, the requirements for teachers are very high, who are required to be not only familiar with the whole set of teaching tools, but also have a solid professional theoretical foundation and practical operation ability, an all-round mastery to and accurate, profound comments on the whole simulation process. Besides, a great deal of experimental preparation work has to be carried out.

(3) Reform the practical teaching system to provide a policy guarantee for sand table simulation teaching

To ensure the teaching effect, sand table simulation requires a lot of consecutive class hours. At 
the same time, due to considering the linkage with theoretical courses, engineering project management sand table simulation practice teaching for $2-3$ weeks is arranged in the $6^{\text {th }}$ semester for the students in the engineering management specialty in developing the teaching plan. This is because the students have principally learned such specialty courses as Construction Engineering Measurement and Pricing, Construction Technology and Construction Organization, Engineering Contract Management, Construction Enterprise Accounting, Engineering Project Management, etc. Due to considering that the lesson preparation workload of the tutors is higher than general theoretical teaching, the calculation of the teaching workload of the tutors should be made favorably as an incentive measure, which can be increased by $30 \%$ from the class hours of a general theoretical course.

\section{Conclusion}

The application of engineering management sand table simulation can alleviate the weak status-quo of the practicing link in the engineering management specialty in schools of higher learning, improve comprehensively the engineering management ability, communication and coordination ability, problem analyzing and solving ability, etc. of students with a good prospect of application. With the information technology being applied at a deeper level, the engineering project management sand table simulation will gradually achieve the simulation of the whole process of an engineering project and the imitation level will be increasingly improved. The sand table simulation will play an increasingly important role in the participative teaching reform in the engineering project management specialty.

\section{Acknowledgement}

In this paper, the research was sponsored by the project of teaching reform and education quality evaluation of Liaoning Education Evaluation Association (Grant NO. PJHYYB15047) and the project of characteristic specialty construction of Dalian Nationalities University.

\section{References}

[1] Shizhao Ding. Construction project management [M]. Beijing: China Architecture and Building Press, 2011. (in Chinese)

[2] Xiuying Hu. Research and practice on the design of engineering bidding simulation course. Sichuan Building Materials, 201238 (3) 255-256. (in Chinese)

[3] Hongtao Li. Project management (PMST) sand table simulation training course [M]. Chongqing: Chongqing University Press, 2013. (in Chinese)

[4] Xiaoyan Dai. Sand table simulation of project management in professional practice teaching of project management[J]. Experimental Technology and Management, 201128 (12) 162-168. (in Chinese)

[5] Hongyong Liu, Junwei Zheng. Study on the engineering project integrated management mode based on the sand table experiment[J]. Science and Technology Progress and Policy, 201027 (19) 20-22. (in Chinese)

[6] Chaoyong Zhang, Jingnan Zhou, Xiaojing Men. Project management sand-table-simulation in the design and practice of a comprehensive course project in construction management[J]. Research and Exploration in Laboratory, 201130 (11) 142-146. (in Chinese)

[7] Cheng Liu. Sand table simulation teaching practice of engineering project management based on BIM[J]. Research and Exploration in Laboratory, 2012 31(10) 433-437. (in Chinese)

[8] Mei Hu. Thinking about improving ERP sand table teaching effect[J]. Laboratory Science, 2015 
18 (2) 97-100. (in Chinese)

[9] Changsheng Li, Qingxia Zhang, Xingxiang Zhao. Scheme design of engineering project management under the mode of CDIO[J]. High Education Press, 2012 (2) 94-97. (in Chinese)

[10] Xiaohui Hu. Discussion of highway project management simulation training course. Journal of Taiyuan Urban Vocational College, 2013 (12) 74-75. (in Chinese) 